\title{
External control of the public water supply in 29 Brazilian cities
}

\section{Suzely Adas Saliba Moimaz(a) Orlando Saliba ${ }^{(a)}$ \\ Fernando Yamamoto Chiba(a) Nemre Adas Saliba ${ }^{(a)}$}

(a) Department of Child and Social Dentistry, Araçatuba Dental School, Unesp - Univ Estadual Paulista, Araçatuba, SP, Brazil.
Declaration of Interests: The authors certify that they have no commercial or associative interest that represents a conflict of interest in connection with the manuscript.

\section{Corresponding author:}

Fernando Yamamoto Chiba

E-mail: fernandoychiba@hotmail.com

Received for publication on Sep 13, 2011 Accepted for publication on Nov 03, 2011
Abstract: The fluoridation of public water supplies is considered the most efficient public health measure for dental caries prevention. However, fluoride levels in the public water supply must be kept constant and adequate for the population to gain preventive benefit. The aim of this study was to analyze fluoride levels in the public water supply of $29 \mathrm{Bra}-$ zilian municipalities during a 48-month period from November 2004 to October 2008. Three collection sites were defined for each source of municipal public water supply. Water samples were collected monthly and analyzed at the Research Laboratory of the Nucleus for Public Health (NEPESCO), Public Health Postgraduate Program, Araçatuba Dental School (UNESP). Of the 6862 samples analyzed, the fluoride levels of $53.5 \%(\mathrm{n}=3671)$ were within the recommended parameters, those of $30.4 \%(n=2084)$ were below these parameters, and those of $16.1 \%$ $(\mathrm{n}=1107)$ were above recommended values. Samples from the same collection site showed temporal variability in fluoride levels. Variation was also observed among samples from collection sites with different sources within the same municipality. Although $53.5 \%$ of the samples contained the recommended fluoride levels, these findings reinforce the importance of monitoring to minimize the risk of dental fluorosis and to achieve the maximum benefit in the prevention of dental caries.

Descriptors: Fluoridation; Fluorine; Water; Oral Health.

\section{Introduction}

The effect of fluoride in dental caries control is widely recognized. Among the proposed means of fluoride provision through public health measures, the fluoridation of water supplies has proven to be a safe, effective, simple, and economical way to significantly reduce the incidence of dental caries. ${ }^{1-6}$ This method was first introduced in Grand Rapids, MI, USA, in 1942. In Brazil, the fluoridation of public water supplies began in 1953, and Baixo Guandu in the state of Espírito Santo was the first Brazilian city to have fluoridated water. ${ }^{7}$ However, water fluoridation was not required in public water supply systems until 1975, when the approval of Federal Law No. 6050 mandated fluoridation in all cities with water treatment plants. ${ }^{8}$

After the implementation of public water supply fluoridation, the rate of dental caries declined considerably in the populations of several Brazilian cities, such as Barretos, SP (55\% reduction after 10 years), ${ }^{9}$ Campinas, SP (57\% after 10 years), ${ }^{10}$ Goiania, GO (57.1\% after 9 years) ${ }^{11}$ and 
Piracicaba, SP (79\% after 25 years)..$^{12}$ These reductions demonstrated the efficacy of this measure in disease control.

Natural levels of fluoride ions in water $>0.01 \mathrm{mg}$ $\mathrm{F} / \mathrm{L}$ are associated with decreased numbers of teeth with caries. ${ }^{1}$ At levels $>1 \mathrm{mg} \mathrm{F} / \mathrm{L}$, teeth increasingly show signs of fluorosis, but no further reduction in the number of teeth affected by caries is achieved., ${ }^{1,2}$ Previous studies have examined the relationship between fluoridated water and the occurrence of dental fluorosis. Catani et al. ${ }^{13}$ evaluated the prevalence of dental fluorosis among schoolchildren in two cities in the state of São Paulo with different means of controlling optimal fluoride concentration in public water supplies; the fluoride concentration was homogeneous in the water of one city and variable in the other. The authors found that most fluorosis was mild, as expected in locations with appropriate fluoride levels, ${ }^{14}$ and that the prevalence of fluorosis was higher among children in the city with better control of fluoride concentration. However, the study did not examine exposure to other fluoride sources, ${ }^{13}$ which has increased the prevalence of dental fluorosis in recent decades. ${ }^{15}$

Thus, mechanisms must be developed to allow the adaptation of fluoride concentrations in public water supplies, thereby increasing the effectiveness of dental caries prevention and control and reducing the prevalence of dental fluorosis. ${ }^{2,7}$ In addition to the control of fluoride concentrations performed by sanitation companies, external control by sanitary monitoring agencies or other public or private institutions is necessary. Such external control should include the monitoring and periodic review of fluoridation by institutions that are not directly responsible for water treatment and supply. ${ }^{2}$ To achieve the maximum benefit in the prevention of dental caries, water fluoridation methods must be rigorously controlled to avoid unwanted effects associated with overdosing, as well as inefficient prevention resulting from underdosing. ${ }^{7}$

Given the importance of the continuous maintenance of fluoride levels within recommended limits, this study analyzed fluoride levels in the public water supplies of 29 Brazilian cities during a 48-month period. Fluoride concentrations were tested to deter- mine whether they were within the recommended range, and temporal variability in fluoride levels within the study period was examined.

\section{Methodology}

In this longitudinal study conducted from November 2004 to October 2008, fluoride levels were analyzed in the public water supplies of 29 cities in northwestern São Paulo State, Brazil. The researchers obtained water supply system data from the secretaries of health, oral health coordinators, and those responsible for the public water supply in each municipality. All cities $(n=40)$ belonging to Regional Health Department II (RHDII) were considered for inclusion in the analysis; cities that did not fluoridate water $(n=4)$, those that did not send samples to the Laboratory of Research, Nucleus for Public Health (NEPESCO), Araçatuba Dental School (UNESP; $n=2$ ), and those that reported the initiation of public water supply fluoridation after the start of the study period $(\mathrm{n}=5)$ were excluded.

\section{Determination of water collection sites}

The collection sites were established based on the number and location of supply sources and water treatment plants (WTPs) in each municipality. Three collection sites for each water supply source or WTP were selected randomly using street addresses; to facilitate site access and prevent sample loss, the collection sites were located in public places such as schools, parks, and commercial properties.

\section{Collection of water samples}

The researchers collected samples in polyethylene bottles that had been decontaminated with deionized water and were identified with labels indicating the location of the collection site, date, and name of the collector. ${ }^{16}$ The samples were collected once a month on a weekday and analyzed by the technical team within 7 days after collection.

\section{Analysis of fluoride levels in water}

Samples from 193 collection sites were analyzed monthly in duplicate for 48 months at the NEPESCO Laboratory of UNESP. Fluoride levels were determined using an ion analyzer (Model 940EA; 
Orion Research, Inc., Beverly, USA) coupled to a specific electrode (Model 9609BN; Orion Research, Inc.) for fluoride. Equipment calibration was performed in triplicate to reduce the margin of error, taking into account the expected range of sample values (0.1-2.0 mg F/L). For this purpose, dilutions from a standard 100-mg/L fluoride solution (Model 940907; Orion Research, Inc.) were used; $1 \mathrm{~mL}$ was collected from each standard after the addition of $1 \mathrm{~mL}$ total ionic strength adjustor buffer (TISAB II; Orion Research, Inc.), an ionic $\mathrm{pH}$ adjustment buffer with non-complex strength that is used widely in fluorine analysis. The values obtained from duplicate analyses of samples after the addition of TISAB II (1:1), were transferred to a Microsoft Excel spreadsheet and converted from $\mathrm{mV}$ to $\mathrm{mg} F / \mathrm{L}$.

In accordance with the average maximum daily temperature, the optimal fluoride concentration in water intended for human consumption in São Paulo State, Brazil, is $0.7 \mathrm{mg} \mathrm{F} / \mathrm{L} .{ }^{17}$ Thus, after mathematical rounding, water samples with average fluoride concentrations of $0.55-0.84 \mathrm{mg}$ F/L were considered to fall within the recommended range of fluoride levels.

\section{Results}

During the 48 months, 6862 water samples were analyzed in duplicate from 193 collection sites in 29 participating municipalities ( $\mathrm{n}=13,724$ analyses). Monthly samples were not collected from some sites due to transportation difficulties or political problems that interfered with site access.

Table 1 shows the number and percentage of samples from the public water supplies of each city, classified according to fluoride level. Of the 6862 samples analyzed, the fluoride levels of $53.5 \%$ ( $\mathrm{n}=3671)$ were within the recommended parameters, those of $30.4 \%(n=2084)$ were below these parameters, and those of $16.1 \%(\mathrm{n}=1107)$ were above recommended values. The proportion of samples from each municipality that fell within the recommended range of fluoride concentration 10.55 $0.84 \mathrm{mg} F / \mathrm{L}$ ) ranged from $13.67 \%$ to $95.74 \%$.

Table 2 presents the number of collection sites, means and standard deviations of fluoride level (mg $\mathrm{F} / \mathrm{L}$ ), and minimum and maximum concentrations (mg F/L) for samples from each municipality during the 48-month study period. Only four municipalities failed to maintain average fluoride concentrations within the recommended parameters.

\section{Discussion}

The fluoridation of public water supplies can efficiently provide public health benefits only through the constant evaluation of the fluoridation process to ensure that adequate fluoride levels are maintained. This monitoring should be conducted by the company responsible for water treatment and distribution and confirmed by an external health authority. ${ }^{2}$ Analysis by another institution enables the cross-checking of results and promotes interaction between institutions in resolving problems arising from the method, equipment, and/or solutions used.

Only $53.5 \%$ of the samples analyzed in this study had fluoride levels within the recommended parameters. The relatively high percentage of samples falling outside of these parameters demonstrates the difficulty that cities face in maintaining constant fluoride levels in drinking water. The majority of samples with fluoride concentrations outside of the recommended range represented underdosing, which has no effect on dental fluorosis or other health risks but provides a minimal benefit in the prevention of dental caries. Variation in fluoride levels was found among samples taken from different collection sites in the same city (Tables 1 and 2 ), indicating the importance of selecting collection sites that are representative of the number and location of supply sources.

Saliba et al. ${ }^{18}$ analyzed similar samples from northwestern São Paulo State during a 6-month period (November 2004 - April 2005), and found a lower percentage $(38.19 \%)$ of water samples with fluoride levels within recommended parameters in comparison with the results of the present study. This temporal increase in the proportion of water samples with appropriate fluoride levels demonstrates the importance of longitudinal studies and the effectiveness of constant monitoring, which facilitates the operational control of water fluoridation procedures and improves the quality of public water supplies. ${ }^{19-23}$ In another study of eight cities 
Table 1 - Classification of samples from the public water supplies of 29 cities in São Paulo State, Brazil, according to fluoride concentration (mg F/L).

\begin{tabular}{|c|c|c|c|c|c|c|c|c|}
\hline \multirow{2}{*}{ City } & \multicolumn{2}{|c|}{$0.6-0.8 \mathrm{mg} \mathrm{F} / \mathrm{L}$} & \multicolumn{2}{|c|}{$<0.6 \mathrm{mg} \mathrm{F} / \mathrm{L}$} & \multicolumn{2}{|c|}{$>0.8 \mathrm{mg} \mathrm{F} / \mathrm{L}$} & \multicolumn{2}{|c|}{ Total } \\
\hline & $n$ & $\%$ & $n$ & $\%$ & $\mathrm{n}$ & $\%$ & $n$ & $\%$ \\
\hline Alto Alegre & 125 & 88.65 & 14 & 9.93 & 2 & 1.42 & 141 & 100 \\
\hline Araçatuba & 246 & 65.25 & 98 & 25.99 & 33 & 8.75 & 377 & 100 \\
\hline Auriflama & 114 & 83.82 & 22 & 16.18 & 0 & 0 & 136 & 100 \\
\hline Bento de Abreu & 99 & 68.75 & 40 & 27.78 & 5 & 3.47 & 144 & 100 \\
\hline Birigui & 290 & 39.51 & 177 & 24.52 & 267 & 35.97 & 734 & 100 \\
\hline Brejo Alegre & 95 & 71.97 & 30 & 22.73 & 7 & 5.3 & 132 & 100 \\
\hline Castilho & 376 & 58.93 & 158 & 24.76 & 104 & 16.3 & 638 & 100 \\
\hline Coroados & 134 & 93.06 & 1 & 0.69 & 9 & 6.25 & 144 & 100 \\
\hline Gabriel Monteiro & 135 & 95.74 & 2 & 1.42 & 4 & 2.84 & 141 & 100 \\
\hline Guaraçai & 60 & 13.67 & 336 & 76.54 & 43 & 9.79 & 439 & 100 \\
\hline Guararapes & 106 & 76.81 & 16 & 11.59 & 16 & 11.59 & 138 & 100 \\
\hline Guzolândia & 126 & 89.36 & 8 & 5.67 & 7 & 4.96 & 141 & 100 \\
\hline Ilha Solteira & 118 & 86.13 & 17 & 12.41 & 2 & 1.46 & 137 & 100 \\
\hline Itapura & 77 & 21.63 & 222 & 62.36 & 57 & 16.01 & 356 & 100 \\
\hline Lavínia & 130 & 26 & 276 & 55.2 & 94 & 18.8 & 500 & 100 \\
\hline Lourdes & 121 & 84.03 & 20 & 13.89 & 3 & 2.08 & 144 & 100 \\
\hline Mirandópolis & 136 & 48.23 & 78 & 27.66 & 68 & 24.11 & 282 & 100 \\
\hline Murutinga do Sul & 23 & 16.67 & 109 & 78.99 & 6 & 4.35 & 138 & 100 \\
\hline Nova Castilho & 30 & 25.64 & 58 & 49.57 & 29 & 24.79 & 117 & 100 \\
\hline Nova Independência & 91 & 36.99 & 125 & 50.81 & 30 & 12.2 & 246 & 100 \\
\hline Nova Luzitânia & 42 & 56 & 33 & 44 & 0 & 0 & 75 & 100 \\
\hline Penápolis & 118 & 83.69 & 5 & 3.55 & 18 & 12.77 & 141 & 100 \\
\hline Piacatú & 121 & 84.03 & 19 & 13.19 & 4 & 2.78 & 144 & 100 \\
\hline Rubiácea & 187 & 75.4 & 45 & 18.15 & 16 & 6.45 & 248 & 100 \\
\hline Santópolis do Aguapeí & 120 & 94.49 & 4 & 3.15 & 3 & 2.36 & 127 & 100 \\
\hline Sud Mennucci & 99 & 68.75 & 45 & 31.25 & 0 & 0 & 144 & 100 \\
\hline Suzanápolis & 66 & 25.1 & 68 & 25.86 & 129 & 49.05 & 263 & 100 \\
\hline Turiúba & 117 & 84.78 & 19 & 13.77 & 2 & 1.45 & 138 & 100 \\
\hline Valparaíso & 169 & 47.34 & 39 & 10.92 & 149 & 41.74 & 357 & 100 \\
\hline Total & 3671 & 53.5 & 2084 & 30.4 & 1107 & 16.1 & 6862 & 100 \\
\hline
\end{tabular}

in northwestern São Paulo State conducted during a 36-month period from November 2004 to October 2007, Saliba et al. ${ }^{24}$ found a higher proportion $(77.4 \%)$ of water samples with fluoride levels within recommended parameters. However, it should be noted that these eight cities used a single water source. Our findings highlight the importance of longitudinal studies that monitor fluoride levels in public water supplies, especially for cities in which multiple water sources are integrated into the water supply system, where it is more difficult to control fluoride levels throughout the network.

In a study that monitored municipal control of fluoride levels in Niteroi, RJ, Brazil for 1 year, Maia 
Table 2 - Number of collection sites, mean fluoride level (mg F/L), minimum and maximum concentrations (mg F/L), and standard deviations for water samples from 29 cities in São Paulo State, Brazil, during the 48-month study period.

\begin{tabular}{|c|c|c|c|c|c|}
\hline City & $\begin{array}{c}\text { Number of } \\
\text { collection sites }\end{array}$ & $\begin{array}{c}\text { Mean fluoride level } \\
\text { (mg F/L) }\end{array}$ & $\begin{array}{c}\text { Minimum } \\
\text { concentration } \\
\text { (mg F/L) }\end{array}$ & $\begin{array}{l}\text { Maximum } \\
\text { concentration } \\
(\mathrm{mg} \mathrm{F} / \mathrm{L})\end{array}$ & $\begin{array}{l}\text { Standard } \\
\text { deviation }\end{array}$ \\
\hline Alto Alegre & 3 & 0.64 & 0.35 & 0.88 & 0.08 \\
\hline Araçatuba & 9 & 0.66 & 0.07 & 1.13 & 0.15 \\
\hline Auriflama & 3 & 0.57 & 0.01 & 0.77 & 0.21 \\
\hline Bento de Abreu & 3 & 0.62 & 0.1 & 1.20 & 0.14 \\
\hline Birigui & 43 & 0.70 & 0.01 & 1.67 & 0.33 \\
\hline Brejo Alegre & 3 & 0.66 & 0.43 & 1.05 & 0.12 \\
\hline Castilho & 15 & 0.70 & 0.28 & 2.65 & 0.29 \\
\hline Coroados & 3 & 0.70 & 0.55 & 0.95 & 0.08 \\
\hline Gabriel Monteiro & 3 & 0.69 & 0.50 & 0.91 & 0.07 \\
\hline Guaraçai & 12 & 0.48 & 0.14 & 3.28 & 0.37 \\
\hline Guararapes & 3 & 0.68 & 0.3 & 1.06 & 0.13 \\
\hline Guzolândia & 3 & 0.69 & 0.3 & 0.95 & 0.10 \\
\hline Ilha Solteira & 3 & 0.67 & 0.11 & 5.07 & 0.44 \\
\hline Itapura & 12 & 0.45 & 0.04 & 1.57 & 0.34 \\
\hline Lavínia & 12 & 0.53 & 0.02 & 1.76 & 0.34 \\
\hline Lourdes & 3 & 0.63 & 0.33 & 0.92 & 0.08 \\
\hline Mirandópolis & 6 & 0.71 & 0.05 & 2.72 & 0.30 \\
\hline Murutinga do Sul & 3 & 0.42 & 0.13 & 1.11 & 0.18 \\
\hline Nova Castilho & 3 & 0.67 & 0.09 & 2.21 & 0.43 \\
\hline Nova Independência & 6 & 0.55 & 0.09 & 1.83 & 0.34 \\
\hline Nova Luzitânia & 3 & 0.58 & 0.23 & 0.77 & 0.11 \\
\hline Penápolis & 3 & 0.70 & 0.5 & 1.0 & 0.10 \\
\hline Piacatú & 3 & 0.67 & 0.4 & 2.32 & 0.25 \\
\hline Rubiácea & 6 & 0.65 & 0.06 & 1.37 & 0.14 \\
\hline Santópolis do Aguapeí & 3 & 0.68 & 0.32 & 1.08 & 0.08 \\
\hline Sud Mennucci & 3 & 0.58 & 0.4 & 0.82 & 0.07 \\
\hline Suzanápolis & 9 & 0.79 & 0.17 & 1.53 & 0.33 \\
\hline Turiúba & 3 & 0.61 & 0.43 & 0.91 & 0.07 \\
\hline Valparaíso & 9 & 0.77 & 0.02 & 1.16 & 0.20 \\
\hline Total & 193 & 0.64 & 0.01 & 5.07 & 0.28 \\
\hline
\end{tabular}

et al. ${ }^{25}$ found that treated water showed a wide variation in fluoride concentration $(0.03-1.49 \mathrm{mg} \mathrm{F} / \mathrm{L})$ and $96 \%$ of samples had inadequate concentrations. Thus, the operational control of water fluoridation was inadequate in terms of maintaining fluoride levels in the public water supply. ${ }^{25}$ These findings indicate that the external control of water fluoridation may safely and reliably prevent large variations in fluoride levels in public water supplies. Only 3.4\% of our samples had fluoride levels $>1.2 \mathrm{mg} \mathrm{F} / \mathrm{L}$, and municipalities promptly corrected such fluoride overdosing to avoid the risk of dental fluorosis. During the study period, some cities achieved recommended fluoride levels within 1 month after being 
informed of analytical results. Municipalities with fewer water sources demonstrated greater control of fluoride levels in drinking water.

\section{Conclusion}

Although the majority of water samples from Brazilian municipalities analyzed in this study had appropriate fluoride levels, many samples fell outside of the recommended parameters. This inability to efficiently control fluoride levels can reduce the effectiveness of preventive measures or increase inhabitants' risk of developing dental fluorosis. The great variability in fluoride concentrations among

\section{References}

1. Dean HT, Arnold FA Jr, Elvove E. Domestic water and dental caries, V. additional studies of the relation of fluoride domestic waters to dental caries experience in 4425 white children aged 12-14 years, of 13 cities in 4 states. Public Health Rep. 1942 Aug 7;57(32):1155-94.

2. Narvai PC. Cárie dentária e flúor: uma relação do século XX. Cien Saude Colet. 2000;5(2):381-92.

3. McDonagh M, Whiting P, Wilson PM, Sutton AJ, Chestnutt I, Cooper J, et al. Systematic review of public water fluoridation. BMJ. 2000 Oct;321(7265):855-9.

4. Arnold FA, Likins RC, Russel AL, Scott DB. Fifteenth years of the Grand Rapids fluoridation study. J Am Dent Assoc. 1962 Dec;65(6):780-5.

5. Horowitz HS. The effectiveness of community water fluoridation in the United States. J Public Health Dent. 1996;56(5):2538.

6. Arcieri RM, Saliba CA, Saliba NA, Moimaz SAS, Sundefeld MLMM. Redução da cárie dental em escolares de Araçatuba, após 21 anos de fluoretação da água de abastecimento. Rev Fluminense Saude Colet. 1998;3(3):41-8.

7. Saliba NA, Moimaz SA, Casotti CA, Pagliari AV. Dental caries of lifetime residents in Baixo Guandu, Brazil, fluoridated since 1953: a brief communication. J Public Health Dent. 2008 Spring;68(2):119-21.

8. Brasil. Lei Federal n 6.050, de 24 de maio de 1974. Dispõe sobre a obrigatoriedade da fluoretação das águas em sistema de abastecimento. Diário Oficial da República Federativa do Brasil, Brasília, DF. 27 julho 1975. [cited 2011 Sep 13]. Available from: http://www.saude.rs.gov.br/ dados/1161002922211LEI6050.pdf.

9. Viegas Y, Viegas AR. Análise dos dados de prevalência de cárie dental na cidade de Barretos, SP, Brasil, depois de dez anos de fluoretação da água de abastecimento público. Rev Saude Publica. 1985 Ago;19(4):287-99. samples and municipalities reinforces the importance of external monitoring of the fluoridation of public water supplies, which facilitates operational control in cities and contributes to the improvement of residents' oral health status and quality of life.

\section{Acknowledgements}

The authors would like to thank the Coordination of the Improvement of Higher Education Personnel (CAPES) and the National Council for Scientific and Technological Development (CNPq) for providing financial support for this research.

10. Viegas Y, Viegas AR. Análise dos dados de prevalência de cárie dental na cidade de Campinas, SP, Brasil, depois de dez anos de fluoração da água de abastecimento público. Rev Saude Publica. 1974 Oct-Dec;8(4):399-409.

11. Freire MCM, Pereira MF, Batista MRS, Barbosa MI, Rosa AGF. Prevalência de cárie e necessidade de tratamento entre escolares de 6 a 12 anos de idade, Goiânia, GO, Brasil. Rev Saude Publica. 1997 Feb;31(1):44-52.

12. Basting RT, Pereira AC, Meneghim MC. Avaliação da prevalência da cárie dentária em escolares do município de Piracicaba-SP, Brasil, após 25 anos de fluoretação das águas de abastecimento público. Rev Odontol Univ Sao Paulo. 1997 Oct-Dec;11(4):287-92.

13. Catani DB, Hugo FN, Cypriano S, Sousa MLR, Cury JA. [Relationship between fluoride levels in the public water supply and dental fluorosis]. Rev Saude Publica. 2007 Oct;41(5):7329. Portuguese.

14. Frazão P, Peverari AC, Forni TI, Mota AG, Costa LR. Fluorose dentária: comparação de dois estudos de prevalência. Cad Saude Publica. 2004 Jul-Aug;20(4):1050-8.

15. Clark DC, Berkowitz J. The influence of various fluoride exposures on the prevalence of esthetic problems resulting from dental fluorosis. J Public Health Dent. 1997 Summer;57(3):144-9.

16. Ramires I, Maia LP, Rigolizzo D dos S, Lauris JRP, Buzalaf MAR. [External control over the fluoridation of the public water supply in Bauru, SP, Brazil]. Rev Saude Publica. 2006 Oct;40(5):883-9. Portuguese.

17. Galagan DJ, Vermillion JR. Determining optimum fluoride concentrations. Public Health Rep. 1957 Jun;72(6):491-3.

18. Saliba NA, Moimaz SAS, Tiano AVP. Fluoride level in public water supplies of cities from the northwest region of São Paulo State, Brazil. J Appl Oral Sci. 2006 Sep-Oct;14(5):346-50. 
19. Barros ERC, Tovo MF, Scapini C. Análise crítica da fluoretação de águas no Município de Porto Alegre/RS. RGO. 1990 Jul-Ago;38(4):247-54.

20. Carmo CDS, Alves CMC, Cavalcante PR, Ribeiro CCC. Avaliação da fluoretação da água do sistema de abastecimento público na Ilha de São Luís, Maranhão, Brasil. Cienc Saude Colet. 2010 Jun;15(Supl 1):1835-40.

21. Bellé BLL, Lacerda VR, Carli AD, Zafalon EJ, Pereira PZ. Análise da fluoretação da água de abastecimento público da zona urbana do município de Campo Grande (MS). Cienc Saude Colet. 2009 Jul-Aug;14(4):1261-6.

22. Lima FG, Lund RG, Justino LM, Demarco FF, Del Pino FAB, Ferreira R. Vinte e quatro meses de heterocontrole da fluoretação das águas de abastecimento público de Pelotas,
Rio Grande do Sul, Brasil. Cad Saúde Pública. 2004 MarAbr;20(2):422-9.

23. Silva JS, Val CM, Costa JN, Moura MS, Silva TAE, Sampaio FC. [Monitoring water fluoridation in three cities in Piauí State, Brazil]. Cad Saude Publica. 2007 May;23(5):1083-8. Portuguese.

24. Saliba NA, Moimaz SAS, Saliba O, Barbosa TF. [Fluoride content monitoring of the public water supply of the Northwest area of the state of São Paulo, Brazil: 36-month analysis]. Rev Odonto Cienc. 2009 Oct-Dec;24(4):372-6. Portuguese.

25. Maia LC, Valença AMG, Soares EL, Cury JA. Controle operacional da fluoretação da água de Niterói, Rio de Janeiro, Brasil. Cad Saude Publica. 2003 Jan-Fev;19(1):61-7. 